\title{
Genetic Diversity Analysis in Popular High Yielding Rice Varieties of Kerala, India
}

\author{
R. Das* and V.G. Jayalekshmy \\ Department of Plant Breeding and Genetics, College of Agriculture, Vellayani Kerala \\ Agricultural University, Thrissur, Kerala, India \\ *Corresponding author
}

\section{A B S T R A C T}

\section{Keywords}

Clusters, $\mathrm{D}^{2}$ value,

Divergence, Adaptation, Hybridization

Article Info

Accepted:

20 June 2019

Available Online:

10 July 2019
Twenty one genotypes were grouped into eight clusters based on $\mathrm{D}^{2}$ values for 11 characters. From the inter cluster $\mathrm{D}^{2}$ values of the eight clusters, it was found that the highest divergence occurred between cluster II and VI followed by cluster I and V, cluster IV and VIII, cluster V and VI, cluster V and VIII and cluster IV and V suggesting that the crosses involving varieties from these clusters would give wider and desirable recombination. The variety PTB-9 from cluster VIII, Swarnaprabha from cluster VI and Uma from cluster I having high mean values for grain yield per plant may be directly used for adaptation or may be used as parents in future hybridization programme. Among the 11 quantitative characters studied the most important character contributing to the divergence was filled grains/panicle followed by grain yield/plant, number of grain /panicle, number of spikelets/panicle, number of grains/panicle, plant height and pollen fertility.

\section{Introduction}

Being the most important food crops in the world, rice (Oryza sativa L.) supports over half of the global population. However, alarming threats for rice breeders and agricultural scientists are coming from increase in global population, projected to be 9.2 billion by 2050 , predicted increase in water scarcity and decrease in arable land, and the constant battle against new emerging pathogens and pests and reduced quality due to possible adverse effects from climate change (Khush, 2005). Being staple food, improving productivity and quality traits of rice always remains crucial. Genetic diversity in crop plants is essential to sustain level of high productivity (Tripathi et al., 2013). Generally, in any breeding programme based on the objective, the divergent parents are crossed to develop promising breeding lines having sufficient diversity. The more diverse the parents, within overall limits of fitness, greater are the chances of obtaining higher amount of heterotic expression in $F_{1} s$ and broad spectrum of variability in segregating generations (Chakravorty and Ghosh, 2012).

Therefore, a meaningful classification of genotypes will enable the breeder to identify the best parents with wide genetic divergence and to utilize some of the selected diverse parents in the hybridization programme. In the present study, an attempt was made to classify 
and understand the nature and magnitude of genetic diversity.

\section{Materials and Methods}

The materials used in the research comprised of twenty one local rice varieties (Table 1) of Kerala collected from three different rice research centers representing three soil and climatically different rice growing tracts of Kerala namely Regional Agricultural Research station, Pattambi, Palakkad, Rice Research station, Moncompu, Alappuzha, Kerala and Rice Research station, Mannuthy. Plant varieties were raised in the nursery and seedlings were then transplanted to main field as and when they attend the maturity of 25 days. The recommended package of practices was followed for raising good and healthy crop. At maturity observations were recorded on, plant height $(\mathrm{cm})$, days to flowering, days to maturity, panicle length $(\mathrm{cm})$, Number of tillers plant, number of effective tillers/plant, total number of grains/panicle, filled grains/ panicle, pollen fertility, spikelet fertility percentage and grain yield/plant. The analysis of variance was carried out for all the traits and the data were subjected multivariate analysis following Mahalanobis's $\mathrm{D}^{2}$ statistics (Mahalanobis, 1963) to measure the genetic divergence followed by the clustering of genotypes based on 11 characters following Tocher's method as described by Rao (1952).

\section{Results and Discussion}

Analysis of variance showed significant differences for all the characters studied in the present investigation, indicating a wide range of variation for all the 11 traits. The results of analysis of variance are presented in Table 2.

Twenty one genotypes were grouped into eight clusters based on $\mathrm{D}^{2}$ values using Tocher's method such that the genotypes belonging to same cluster had an average smaller $\mathrm{D}^{2}$ values than those belonging to different clusters. The distribution of genotypes into various clusters is shown in Table 3. Out of eight clusters, cluster I was the largest comprising of 7 varieties followed by clusters VI with four varieties, cluster IV, V, VII and VIII each with 2 varieties, cluster II and III with one genotype each. The clusters II and III were represented by single variety indicating high degree of heterogeneity among the genotypes.

The average intra and inter cluster $\mathrm{D}^{2}$ values are presented in Table 4 . Intra cluster $D^{2}$ values ranged from zero (II and III) to 738.91 (VI). Maximum intra cluster distance was observed in cluster IV (738.91), followed by cluster VI (731.64), cluster VIII (594.18), cluster I (462.41), cluster V (334.71) and cluster IV (165.26), indicating that some genetic divergence still existed among these rice varieties. This could be made use of in the yield improvement through recombination breeding.

From the inter cluster $\mathrm{D}^{2}$ values of the eight clusters, it can be seen that the highest divergence occurred between cluster II and VI (8478.55) followed by cluster $\mathrm{I}$ and $\mathrm{V}$ (7923.47), cluster IV and VIII (7458.16), cluster V and VI (7248.52), cluster V and VIII (6950.62) and cluster IV and V (6421.33) suggesting that the crosses involving varieties from these clusters would give wider and desirable recombination. While the lowest was noticed between cluster III and IV (1009.39), followed by cluster III and VII (1216.17), cluster VI and VIII (1324.52), cluster IV and VII (1409.51), cluster IV and V (1573.1) and cluster I and VI (1676.6).

The cluster means for each of eleven characters are presented in Table 5. From the data it can be seen that considerable differences existed for all the characters under study. The data indicated that the cluster mean 
for Plant height was highest in cluster VII $(110.25 \mathrm{~cm})$ and the lowest in cluster II $(97.5$ $\mathrm{cm})$. Cluster VI recorded the highest number of total tillers per plant VI (11.6) and the lowest number of productive tillers per plant was in cluster IV (9.5). Cluster VIII recorded the highest no of flowering days (62) and the lowest was recorded in cluster II (53.87). The number of productive tillers per panicle was highest in cluster VIII (10.25) and the lowest in cluster IV (8.3). The data indicated that the cluster mean for panicle length was highest in cluster IV $(25.5 \mathrm{~cm})$ and the lowest in cluster $\mathrm{V}(23.25 \mathrm{~cm})$.

Pollen fertility percentage was recorded highest in cluster VIII (87) and the lowest in cluster V (58). Cluster VI recorded the highest grain yield per plant $(15.43 \mathrm{~g})$ while in cluster VIII it was low (6.64 g). Cluster VI recorded highest (177.22) number of spikelets/panicle it was low in cluster V (133). Number of filled grains/panicle was recorded highest in cluster I (157.53) and the lowest in cluster V (108). Cluster III (126.5) recorded the highest number of days to maturity and lowest mean recorded in cluster II (100.5). Number of grains/panicle was recorded highest in cluster VI (168.72) and low in cluster in cluster V (119.33). Cluster VIII recorded the highest grain yield per plant $(26 \mathrm{~g})$ while in cluster $\mathrm{V}$ it was low (19.12g). The result indicates that selection of genotypes having high values for particular trait could be made and used in the hybridization programme for improvement of that character.

Table.1 List of Rice varieties used in the experiment

\begin{tabular}{|c|c|c|}
\hline Searial No & Name of Varieties & Place of collection \\
\hline \multicolumn{3}{|c|}{ Male parents } \\
\hline 1 & PTB-9 & RARS, Pattambi \\
\hline 2 & PTB-10 & RARS, Pattambi \\
\hline 3 & PTB-32 & RARS, Pattambi \\
\hline 4 & Aiswarya & RARS, Pattambi \\
\hline 5 & Annapoorna (PTB-35) & RARS, Pattambi \\
\hline 6 & Jyothi (PTB-39) & RARS, Pattambi \\
\hline 7 & Bharathy (PTB-41) & RARS, Pattambi \\
\hline 8 & Swarnaprabha (PTB-42) & RARS, Pattambi \\
\hline 9 & Mattatriveni (PTB-45) & RARS, Pattambi \\
\hline 10 & Jayathi (PTB-46) & RARS, Pattambi \\
\hline 11 & Neeraja (PTB-47) & RARS, Pattambi \\
\hline 12 & Kanchana (PTB-50) & RARS, Pattambi \\
\hline 13 & Manupriya & RRS, Mannuthy \\
\hline 14 & Varsha (PTB-56) & RARS, Pattambi \\
\hline 15 & Kanakom (MO-11) & RRS, Moncombu \\
\hline 16 & Karthika (MO-7) & RRS, Moncombu \\
\hline 17 & Aruna (M0-8) & RRS, Moncombu \\
\hline 18 & Remya (MO-10) & RRS, Moncombu \\
\hline 19 & Aruna (MO-8) & RRS, Moncombu \\
\hline 20 & Pavizham (MO-6) & RRS, Moncombu \\
\hline 21 & Uma (M0-16) & RRS, Moncombu \\
\hline
\end{tabular}


Table.2 ANOVA variance table for 12 different characters

\begin{tabular}{|l|l|l|l|l|}
\hline $\begin{array}{l}\text { S. } \\
\text { No. }\end{array}$ & Characters & $\begin{array}{l}\text { Replication } \\
\text { df:2 }\end{array}$ & $\begin{array}{l}\text { Genotypes } \\
\text { df;47 }\end{array}$ & $\begin{array}{l}\text { Error } \\
\text { df:94 }\end{array}$ \\
\hline 1 & Plant height $(\mathrm{cm})$ & 0.130 & $138.024^{* *}$ & 1.104 \\
\hline 2 & Total no of tillers/plant & 0.238 & $2.243^{* *}$ & 0.579 \\
\hline 3 & Days to flowering & $7.434^{* *}$ & $45.768^{* *}$ & 0.796 \\
\hline 4 & Number of Productive tillers/plant & 0.537 & 1.8228 & 0.802 \\
\hline 5 & Panicle length $(\mathrm{cm})$ & $1.773^{*}$ & $7.408^{* *}$ & 0.843 \\
\hline 6 & Pollen fertility \% & 0.760 & $192.526^{* *}$ & 1.937 \\
\hline 7 & Number of Spikelets /panicle & $2.171^{* *}$ & $592.989^{* *}$ & 0.513 \\
\hline 8 & Number of Filled grain /panicle & 0.666 & $912.829^{* *}$ & 1.057 \\
\hline 9 & Number of grain /panicle & 0.595 & $118.445^{* *}$ & 0.945 \\
\hline 10 & Number of grain /panicle & 1.180 & $558.417^{* *}$ & 3.060 \\
\hline 11 & Grain yield/plant (g) & 0.003 & $13.699^{* *}$ & 0.930 \\
\hline
\end{tabular}

Table.3 Classification of genotypes into different clusters

\begin{tabular}{|l|l|l|}
\hline Cluster & Number of genotypes & Germplasms \\
\hline I & 7 & $\begin{array}{l}\text { Remya, Manupriya, Bharathy, Uma, } \\
\text { Jyothi, Karthika, Pavizham }\end{array}$ \\
\hline II & 1 & Mattatriveni \\
\hline III & 1 & Neeraja \\
\hline IV & 2 & Varsha, Hraswa \\
\hline V & 2 & PTB 32, PTB 10 \\
\hline VI & 4 & $\begin{array}{l}\text { Jayathi, Swarnaprabha, Kanakom, } \\
\text { Aiswarya }\end{array}$ \\
\hline VII & 2 & Annapoorna, Kanchana \\
\hline VIII & 2 & PTB 9, Aruna \\
\hline
\end{tabular}

Table.4 Intra (diagonal) and inter clusters values and extant of diversity among the clusters

\begin{tabular}{|l|l|l|l|l|l|l|l|l|}
\hline & I & II & III & IV & V & VI & VII & VIII \\
\hline I & 462.41 & 4823.88 & 3317.59 & 5320.96 & 7923.47 & 1676.6 & 2138.42 & 2354.69 \\
\hline II & & 0 & 4466.51 & 2586.62 & 5680.71 & 8478.55 & 2473.51 & 8125.9 \\
\hline III & & & 0 & 1009.39 & 2953.68 & 3473.36 & 1216.17 & 5496.55 \\
\hline IV & & & & 165.26 & 1573.1 & 6421.33 & 1409.51 & 7458.16 \\
\hline V & & & & & 334.71 & 7248.52 & 2678.36 & 6950.62 \\
\hline VI & & & & & & 738.91 & 2868.87 & 1324.52 \\
\hline VII & & & & & & & 731.64 & 3224.1 \\
\hline VIII & & & & & & & & 594.18 \\
\hline
\end{tabular}


Int.J.Curr.Microbiol.App.Sci (2019) 8(7): 2758-2764

Table.5 Cluster mean for eleven characters

\begin{tabular}{|c|c|c|c|c|c|c|c|c|c|c|c|}
\hline & $\begin{array}{c}\text { PH } \\
(\mathrm{cm})\end{array}$ & TTPP & DF & NPTP & PL & PF & NSPP & NFGP & $\mathrm{DM}$ & NGP & GYP \\
\hline I & 99.75 & 11.318 & 55.53 & 10.15 & 23.92 & 81.28 & 176.79 & 157.53 & 116.14 & 165.42 & 25.50 \\
\hline II & 97.5 & 10.25 & 53.87 & 9.22 & 23.5 & 77.5 & 152 & 112.93 & 100.5 & 166.5 & 22.5 \\
\hline III & 101 & 10.66 & 55.83 & 8.5 & 24.1 & 87 & 149.5 & 127 & 126.5 & 152 & 20.57 \\
\hline IV & 98.89 & 9.5 & 54.19 & 8.29 & 25.49 & 77.32 & 138.16 & 110.56 & 116 & 140.80 & 20.29 \\
\hline V & 102 & 10.82 & 56.41 & 9.5 & 23.25 & 58 & 133 & 108 & 105.25 & 119.33 & 19.12 \\
\hline VI & 110.25 & 11.6 & 60.92 & 10.24 & 24.48 & 84.37 & 177.22 & 156.96 & 115.37 & 168.72 & 25.54 \\
\hline VII & 103.25 & 10.63 & 56.94 & 9.20 & 23.13 & 81.32 & 159.25 & 129.25 & 106.5 & 152.52 & 22.37 \\
\hline VIII & 112.5 & 11.5 & 62 & 10.25 & 23.25 & 61.5 & 176.58 & 157.45 & 102.25 & 162.65 & 26 \\
\hline
\end{tabular}

PH- Plant height, TTPP- Tillers no of tillers/plant, DF- Days to flowering, NPTP- Number of productive tillers/plant, PL- Panicle length, PF\%- Pollen fertility \%, NSPP- Number of spikelet/panicle, NFGP- Number of filled grain/panicle, DM- Days to maturity, L:b- Length-breadth ratio, NGP- Number of grain/panicle, GYP- Grain yield/plant 
Table.6 Contribution of characters towards genetic divergence

\begin{tabular}{|l|l|c|}
\hline Sl No & Character & Contribution \% \\
\hline 1 & Plant height $(\mathrm{cm})$ & 3 \\
\hline 2 & Total no of tillers/plant & 0 \\
\hline 3 & Days to flowering & 0 \\
\hline 4 & Number of productive tillers/plant & 0 \\
\hline 5 & Panicle length & 0 \\
\hline 6 & Pollen fertility \% & 1 \\
\hline 7 & Number of spikelets /panicle & 11 \\
\hline 8 & Number of filled grains /panicle & 43 \\
\hline 9 & Days to maturity & 15 \\
\hline 10 & Number of grains /panicle & 7 \\
\hline 11 & Grain yield/plant & 20 \\
\hline
\end{tabular}

The results showed that the contribution of Filled grain /panicle was highest towards genetic divergence (43\%) followed by grain yield/plant (20\%), number of grain /panicle $(15 \%)$, spikelet's /panicle $(11 \%)$, number of grain /panicle (7\%), plant height (3\%) and pollen fertility percentage (1\%) (Table 6). No contribution towards genetic divergence was from the traits total number of tillers/plant, days to flowering, productive tillers/plant and Panicle length.

It is assumed that maximum amount of heterosis will be manifested in cross combinations involving the parents belonging to most divergent clusters. The inter-cluster $\mathrm{D}^{2}$ values ranged widely with minimum distance between clusters III and IV and maximum distance between clusters II and VI indicating high diversity among the genotypes of these clusters. It is reported that genotypes within the cluster with high degree of divergence would produce more desirable breeding materials for achieving maximum genetic advance. Therefore the maximum amount of heterosis is expected from the crosses with parents belonging to the most divergent clusters as has been reported by Prasad et al., (2013), Allam et al., (2014), Kumar et al., (2014) and Bharathi et al., (2016). Hence, it is desirable to select the genotypes from the cluster showing high inter-cluster distance in breeding programme for obtaining the desirable segregants. The inter-cluster distances were higher than the intra-cluster distances indicating the presence of wider genetic diversity between the clusters rather than within the clusters.

It is observed that no cluster contained at least one genotype with all the desirable traits, which ruled out the possibility of selecting directly one genotype for immediate use. Therefore, hybridization between the selected genotypes from divergent clusters is essential to judiciously combine all the targeted traits.

Genotype groups in cluster V were with low grain yields per plant associated with low pollen fertility, less spikelet/panicle and less no of filled grain/panicle and Genotypes in cluster VIII had grain yields per plant associated with higher plant height and higher number of productive tillers/plant. Higher yielding clusters were VIII, VI, I. The variety PTB 9 from cluster VIII, Swarnaprabha from cluster VI and Uma from cluster I having high mean values for grain yield per plant may be directly used for adaptation or may be used as parents in future hybridization programme as has been reported Kumar et al., (2014) and Bharathi et al., (2016). 
Among the 11 quantitative characters studied the most important character contributing to the divergence was number of filled grains/panicle followed by grain yield/plant, number of grains/panicle, number of spikelets/panicle, number of grains/panicle, plant height and pollen fertility, these results have conformity with reports of Allam et al., (2014), Rajput et al., (2014), Kumar et al., (2014) and Bharathi et al., (2016). In order to select genetically diverse genotypes the material should be screened for the above mentioned important traits.

\section{References}

Allam, C.R., Jaiswal, H.K., and Qamar, A. 2014. Divergence analysis for yield and quality traits in some indigenous basmati rice genotypes [Oryza sativa L.]. International Journal of Applied Biology and Pharmaceutical Technology. 5 (4): 257263.

Bharathi, G., Krishna Veni, B., Lal Ahamed M., and Jaya Lalitha, K. 2016. Studies on Genetic Divergence in High Yielding Rice (Oryza sativa L.) Genotypes. Journal of Rice Research. 9 (2):6-10.

Chakravorty, A., and Ghosh, P. D. 2012. Genetic divergence in landraces of rice (O. sativa L.) of West Bengal, India. Journal of Crop and Wee. 8(2):23-28.
Khush, G. S. 2005. What it will take to feed five billion rice consumers by 2030. $\mathrm{Pl}$. Mol. Biol., 59:1-6.

Kumar, S, Dwivedi S.K., Singh, S.S., Jha, S.K., Lekshmy, S., Elanchezhian, R., Singh, O.N., Bhatt, B.P. 2014. Identification of drought tolerant rice genotypes by analysing drought tolerance indices and morphophysiological traits. SABRAO J. Breed. Genet. 46 (2): 217-230.

Mahalanobis, P.C. 1963. On the Genaralised Distance in Science, India. 2:49 55.

Prasad, S., Krishna, G. R., Rao, K.V.S., Padmaja, L.V., and Chaitanya, U. 2013. Diversity analysis of indica rice (Oryza sativa 1.) genotypes against low and high temperature stress. Journal of Agriculture and Veterinary Science. 4 (6): 34-39.

Rajput, A.S., Suresh B.G., and Bhatti, M. 2014. Genetic diversity of irrigated medium duration of rice genotypes suited for eastern plain zone of U.P. Journal of Agriculture and Veterinary Science.7 (3): 42-45.

Rao, C. R.1952. Advance Statistical Method for Biometrical Research. John Wiley and Sons, New York, pp-390.

Tripathi, R.P., Sharma, P., and Singh, S. 2005. Tillage index: An approach to optimize tillage in rice-wheat system. Soil Tillage Research. 80: 125-137.

\section{How to cite this article:}

Das, R. and Jayalekshmy, V.G. 2019. Genetic Diversity Analysis in Popular High Yielding Rice Varieties of Kerala, India. Int.J.Curr.Microbiol.App.Sci. 8(07): 2758-2764. doi: https://doi.org/10.20546/ijcmas.2019.807.344 